\title{
PERDEBATAN HUKUMAN MATI DI INDONESIA: Suatu Kajian Perbandingan Hukum Islam dengan Hukum Pidana Indonesia
}

\author{
Muhammad Hatta \\ Fakultas Hukum Universitas Malikussaleh \\ Jl. Jawa, Lhokseumawe, Aceh, 24351 \\ e-mail: delicten@yahoo.com
}

\begin{abstract}
Abstrak: Secara tegas, hukum pidana Islam dan Indonesia mengatur tentang hukuman mati. Tetapi, di Indonesia eksistensi hukuman mati masih menjadi perdebatan. Ada pendapat bahwa hukuman mati bertentangan dengan Hak Asasi Manusia (HAM) dan ada juga menilai hukuman mati dimaksudkan untuk melindungi kepentingan umum. Untuk mengkaji pertentangan pandangan tersebut, perlu dilakukan analisis secara kritis dengan mengunakan pendekatan yuridis normatif. Disimpulkan bahwa dalam pelaksanaan hukuman mati, baik hukum pidana Islam maupun Indonesia memberlakukan secara hati-hati dan dengan batasan yang telah ditentukan oleh undangundang. Dengan batasan-batasan inilah diharapakan dapat mengimbangi pandangan antara yang mendukung dan menolak hukuman mati di Indonesia. Hukuman mati dalam hukum pidana Islam untuk melindungi agama, jiwa, harta, akal, dan keturunan yang merupakan karunia Allah SWT. yang harus dilindungi, di mana pelanggarnya pantas dihukum mati.
\end{abstract}

\begin{abstract}
The Debate of Capital Punishment in Indonesia: A Comparative Study between Islamic and Indonesian Criminal Law. Strictly speaking, the Islamic and Indonesian criminal law provide for capital punishment. However, the existence of the death penalty in Indonesia is still debatable. It is assumed that the death penalty is against human rights, but others consider it as to protect the public interest. In order to discuss the contravening views, this paper is an attempt to critically analyzed the issu by using a normative juridical approach. It is concluded in its implementation of capital punishment both the in Islamic and Indonesian criminal law is carefully applied and with the limits prescribed by law. Such restrictions are expected to balance the views between the pro and against capital punishment in Indonesia. The death penalty in Islamic criminal law is to protect religion, life, property, intellect and descendant. The five basic human rights is given by the Almighty God that should be protected, the violator of which is liable for capital punishment.
\end{abstract}

Kata Kunci: hukuman mati, hukum pidana, Islam 


\section{Pendahuluan}

Jenis pemidanaan (hukuman) yang paling banyak menimbulkan perdebatan adalah pemidanaan mati. Bahkan negara maju yang mengaku telah menghapus hukuman mati pun, masih juga menerapkan hukuman mati terhadap delik-delik tertentu. Meski sudah menjadi wacana klasik, pro-kontra seputar penerapan hukuman mati ${ }^{1}$ tetap menjadi perdebatan serius di kalangan masyarakat dunia, termasuk di Indonesia. Walaupun secara global menolak hukuman mati, tetapi pelaksanaan hukuman mati justru masih diterapkan di Indonesia. ${ }^{2}$

Tabel: 1.1. Negara-negara yang telah Menghapus Hukuman Mati

\begin{tabular}{|c|l|c|}
\hline No & \multicolumn{1}{|c|}{ Uraian } & Jumlah \\
\hline 1 & $\begin{array}{l}\text { Negara yang menghapus hukuman mati untuk seluruh } \\
\text { kategori kejahatan }\end{array}$ & 94 \\
\hline 2 & $\begin{array}{l}\text { Negara yang menghapus hukuman mati untuk kategori } \\
\text { kejahatan pidana biasa }\end{array}$ & 9 \\
\hline 3 & $\begin{array}{l}\text { Negara yang melakukan moratorium praktik hukuman } \\
\text { mati }\end{array}$ & 39 \\
\hline 4 & $\begin{array}{l}\text { Total negara yang melakukan abolisi (penghapusan) } \\
\text { terhadap hukuman mati }\end{array}$ & 142 \\
\hline 5 & Negara yang masih menerapkan praktik hukuman mati & 55 \\
\hline
\end{tabular}

Sumber: Amnesty International \& Hands off Cain tahun 2007

Berdasarkan data dariAmnesty Internasional, pada tahun 2005 ada sebanyak 2.148 orang yang dieksekusi mati dari 22 negara. 94 persen terjadi di empat negara yaitu Republik Rakyat Cina (RRC) 1.770 orang, Iran 94 orang, Arab Saudi 86 orang dan Amerika Serikat 60 orang. Sedangkan, pada tahun 2006, ada 1.591 orang yang dieksekusi mati dari 25 negara. Secara geografis angka tersebut meningkat, namun jumlah eksekusi menurun. Amnesty International memperkirakan masih terdapat 20.000 orang di dunia yang akan dihukum mati. ${ }^{3}$

Dalam kurun 11 tahun terakhir (1998-2009), Indonesia telah melakukan eksekusi hukuman mati sebanyak 20 orang. Jumlah ini jauh lebih besar dibandingkan pada tahun 1945-2003 yang hanya mengeksekusi mati sebanyak 15 orang. ${ }^{4}$ Karena itu, berdasarkan

${ }^{1}$ Andi Hamzah et al., Pidana Mati di Indonesia di Masa Lalu, Masa Kini dan Masa yang Akan Datang, cet. 2 (Jakarta: Ghalia Indonesia, 1985), h. 2.

${ }^{2}$ Badan Pekerja Kontras, "Praktik Hukuman Mati di Indonesia," diakses dalam http:// www.kontras.org/hmati/data/Working\%20Paper_Hukuman_Mati_di_Indonesia.pdf,diunduh. 30 Desember 2008.

3"Death Penalty Development in 2005," dalam Amnesty International, diakses dalam http://web.amnesty.org/pages/deathpenalty-developments2005-eng.

${ }^{4}$ William Schabas, "Discussion on Death Penalty Contemporary Challenges," dalam Delegation 
catatan Amnesty International, negara Indonesia adalah salah satu negara yang paling banyak menjatuhkan hukuman mati. ${ }^{5}$

Secara yuridis formal, penerapan hukuman mati di Indonesia memang dibenarkan. Hal ini bisa ditelusuri dari beberapa pasal yang ada di dalam Kitab Undang-undang Hukum Pidana (KUHP). Selain itu, hukuman mati juga terdapat di dalam undang-undang di luar KUHP, misalnya Undang-Undang Teroris, Korupsi, Pencucian Uang dan masih banyak lagi. Hal ini menunjukkan bahwa hukuman mati di Indonesia semakin eksis dalam sistem hukum pidana di Indonesia. ${ }^{6}$

Salah satu kebijakan yang penting dalam mempertahankan hukuman mati dalam sistem hukum pidana Indonesia adalah terlihat dari pernyataan Wakil Presiden Jusuf Kalla yang dengan tegas menolak usulan dari Uni Eropa agar Indonesia menghapuskan pemidanaan mati pada rancangan KUHP yang baru. ${ }^{7}$ Bahkan pada tingkat kebijakan terhadap delik-delik tertentu, Presiden Republik Indonesia menegaskan bahwa tidak akan memberikan grasi terhadap para terpidana mati tindak pidana narkoba. ${ }^{8}$

Namun, eksistensi hukuman mati tersebut tidak serta merta disetujui oleh seluruh kelompok masyarakat di Indonesia. Ada yang beranggapan bahwa hukuman mati bertentangan dengan konstitusi yang ada. Bahkan, untuk pertama kalinya permasalahan hukuman mati diajukan di hadapan Mahkamah Konstitusi (MK), karena dianggap bertentangan dengan Undang-Undang Dasar 1945, yaitu bertentangan dengan hak hidup yang dijamin berdasarkan Pasal 28I ayat (1) UUD 1945. ${ }^{9}$

Secara umum, para aktivis atau pegiat Hak Asasi Manusia (HAM) di Indonesia menolak pemberlakuan hukuman mati. Bahkan Komisi Nasional Hak Asasi Manusia (Komnas HAM) juga berpandangan bahwa hukuman mati tidak layak diterapkan di Indonesia. Apabila dikaitkan dengan pemberantasan suatu kejahatan maka tidak ada suatu jaminan dengan menerapkan hukuman mati akan mengurangi suatu kejahatan.

of European Commission and Departemen of Philosofy Faculty of Humanities University of Indonesia, Hotel Mandarin Jakarta, 14 Desember 2004. Tulisan ini kemudian dikutip oleh Komnas HAM dalam websitenya www.komnasham.go.id. 4 Januari 2009.

${ }^{5}$ Sudi Prayitno, "Dilema Hukuman Mati," dalam http://www.legalitas.org/?q=content/ dilema-hukuman-mati. 30 Desember 2008.

${ }^{6} \mathrm{http}: / /$ www.legalitas.org/?q=content/dilema-hukuman-mati. 30 Desember 2008.

${ }^{7}$ Usulan Uni Eropa tersebut disampaikan oleh Dubes Finlandia, Markku Nilnloja, Dubes Jerman, Joachim Broudre Groger, serta delegasi Komisi Uni Eropa, dan Ulrich Eckle. Dalam Media Indonesia, 5 Juli 2006.

${ }^{8}$ The Jakarta Post, 1 Juli 2006 dan Tempo, 1 Juli 2006.

${ }^{9}$ Uji materil (judicial review) hukuman mati tersebut dilakukan terhadap beberapa terpidana mati yang melakukan tindak pidana narkotika berdasarkan Undang-Undang No. 22 Tahun 1997 Tentang Narkotika. Mereka beranggapan bahwa hukuman mati tersebut bertentangan dengan Undang-Undang Dasar 1945. Melalui uji materil inilah yang akan nantinya menilai apakah hukuman mati tersebut bersifat konstitusional ataupun tidak. Pan Mohamad Faiz, "Perdebatan Konstitusionalitas Hukuman Mati," dalam the Jakarta Post, 4 Mei 2007. 
Dalam lingkup masyarakat internasional, pengakuan terhadap hukuman mati hampir tidak mempunyai tempat terhadap masyarakat yang demokratis dan berbudaya. Menurut Perserikatan Bangsa-Bangsa (PBB), walaupun hukuman mati belum dilarang secara tegas di dalam hukum internasional, kecenderungan terhadap pelarangan tersebut sangatlah jelas. Adopsi terhadap Kovenan Internasional terhadap Hak Sipil dan Politik tahun 1989 menunjukkan pengakuan yang sangat tegas oleh masyarakat internasional terhadap penghapusan pemidanaan mati secara menyeluruh.

Berdasarkan konsensus masyarakat internasional yang melawan hukuman mati, beberapa negara retensionis, yaitu negara yang masih menerapkan hukuman mati, menjadi semakin terisolasi. Indonesia, sebagai salah satu negara retensionis, telah meratifikasi berbagai instrumen HAM internasional seperti Kovenan Internasional terhadap Hak Sipil dan Politik, tetapi Indonesia tetap tidak menghapus hukuman mati.

Keteguhan sikap pemerintah Indonesia mempertahankan hukuman mati senada dengan aturan yang diterapkan dalam hukum pidana Islam, di mana terhadap delik-delik tertentu seperti tindak pidana zina muhshan, pembunuhan sengaja, perampokan dan dijatuhi dengan hukuman mati. Masyarakat Indonesia yang dominan beragama Islam, hukuman mati bukanlah hal yang baru bagi masyarakat Indonesia. Namun perbedaan pendapat terhadap hukuman mati di dalam hukum pidana Indonesia adalah terletak pada jenisjenis kejahatan dan pelaksanaan hukuman mati.

Pada prinsipnya, yang terpenting adalah kedua sitem ini mengakui eksistensi hukuman mati dan ini tidak ada perdebatan sama sekali karena secara tegas telah diatur oleh kedua sistem hukum ini. Namun, seiring dengan maraknya gagasan humanisme atau nilai-nilai kemanusiaan universal yang merebak seusai perang dunia kedua, hukuman mati dianggap tidak logis dalam kehidupan modern. ${ }^{10}$ Dengan kata lain, menurut para pembela HAM, dinamisasi hukum pidana di dunia saat ini telah bergeser dari teori pembalasan ke teori rehabilitasi, di mana teori tersebut bersifat clinic treatment. ${ }^{11}$

Pada akhirnya, muncullah perdebatan di kalangan masyarakat seputar perlu tidaknya penerapan hukuman mati di Indonesia saat ini. ${ }^{12}$ Alih-alih menemukan titik temu atau kesepahaman, perdebatan seputar hukuman mati, justru semakin meruncing. Kedua aliran yang mendukung dan menolak hukuman mati kian kukuh dengan argumennya masingmasing, bahkan cenderung ekstrem, sehingga melupakan kaidah-kaidah ilmiah dan ilmu pengetahuan.

${ }^{10} \mathrm{~J}$. E. Sahetapi, Suatu Studi Khusus Mengenai Ancaman Pidana Mati terhadap Pembunuhan Berencana (Jakarta: Rajawali, 1982), h. 202.

${ }^{11}$ Kompas, 29 Pebruari 2003.

${ }^{12}$ J. E. Sahetapi, Suatu Studi Khusus Mengenai Ancaman Pidana Mati, h. 215. 


\section{Hukuman Mati dalam Hukum Pidana Islam}

Dalam istilah bahasa Arab hukuman dikenal dengan kata ('uqûbah) yang berarti siksa atau hukuman, yaitu hukuman atas perbuatan yang melanggar ketentuan Syar'i yang ditetapkan untuk kemaslahatan masyarakat. Menurut 'Abd al-Qadîr 'Audah hukuman adalah pembalasan yang ditetapkan untuk kemaslahatan masyarakat, karena adanya pelanggaran-pelanggaran atas ketentuan syara':

Syaikh Wahbah Zuhailî membagi hukuman dalam Islam menjadi dua bentuk, yaitu: hukuman akhirat (al-uqûbah al-ukhrawiyah) dan hukuman dunia (al-uqûbah al-dunyawiyah). Hukuman akhirat merupakan kehendak Allah SWT., adalah hukuman yang benar (haqq) dan adil ('adl). Ia dapat berbentuk azab atau ampunan dari-Nya. Adapun hukuman dunia menurutnya ada dua macam pula, yaitu hudûd dan ta'zîr. ${ }^{13}$

Dalam hukum pidana Islam, hukuman mati merupakan bentuk hukuman maksimal yang memiliki dasar hukum yang kuat. ${ }^{14}$ Ini menunjukkan bahwa hukum Islam masih mempertahankan hukuman mati untuk tindak kejahatan tertentu, di mana esensi penerapannya bertujuan untuk melindungi kepentingan individu dan masyarakat dari tindak kejahatan yang membahayakan sendi-sendi dasar kemanusiaan. ${ }^{15}$

Dalam hukum Islam, hukuman mati bisa ditemukan dalam tiga bentuk pemidanaan, yaitu qishâsh, hudûd dan ta'zîr. Dalam masalah qishâsh, ancaman hukuman mati ditujukan bagi pelaku pembunuhan yang disengaja atau direncanakan. ${ }^{16}$ Dalam masalah hudûd, ancaman hukuman mati ditujukan bagi pelaku zina muhshan, hirâbah, al-baghyu, dan riddah. Sedangkan dalam masalah $t a ' z i ̂ r$, ancaman hukuman mati ditujukan bagi pelaku kejahatan di luar qishâsh dan hudûd yang oleh negara (penguasa) dianggap sangat berbahaya bagi kelangsungan hidup dan kemaslahatan masyarakat. ${ }^{17}$

Hukuman mati yang diberlakukan untuk kasus-kasus tertentu, semisal narkoba, terorisme dan korupsi, termasuk kategori hukuman ta'zîr yang disebut dengan 'al-qatlu alsiyâsi', yaitu hukuman mati yang tidak diatur oleh al-Qur'an dan Sunnah, tapi diserahkan

\footnotetext{
${ }^{13}$ Imam Yahya, "Hukuman Mati Perspektif Syari'ah," dalam http://imamyahya.blogspot.com/ 2009/04/hukuman-mati-perspektif-syariah.html. Selasa, 14 April 2009.

${ }^{14}$ Q. S. al-Baqarah/2: 179.

${ }^{15}$ Abd al-Wahab al-Khalâf, Science Ushûl al-Fiqh (Kuwait: Dâr al-Qalam, 1992), h. 198; Lihat juga dalam buku Muhammad Abû Zahrah, Ushûl al-Fiqh (Kairo: Maktabah Muhaimar, 1957), h. 351.

${ }^{16}$ 'Abd al-Qadir Audah, al-Tasyri' al-Islâmi Jina’iy: Muqâranah bi al-Qanûn al-Wadh'i, Juz I (Beirut: al-Risâlah Mu'assasah, 1992), h. 663.

${ }^{17}$ Ibid.
} 
kepada negara, baik pelaksanaan ataupun tatacara eksekusinya. ${ }^{18}$ Hukuman mati tersebut boleh diberlakukan oleh suatu negara jika dipandang sebagai upaya efektif menjaga ketertiban dan kemaslahatan masyarakat. ${ }^{19}$

Adanya ancaman hukuman mati dalam Islam, menurut Barda Nawawi Arief, pada hakikatnya bukanlah sarana utama untuk mengatur, menertibkan, atau melindungi masyarakat, tetapi lebih merupakan jalan hukum terakhir, seperti halnya amputasi dalam kedokteran yang sebenarnya bukan obat utama, tetapi sebuah pengecualian sebagai sarana pengobatan terakhir. ${ }^{20}$ Dengan demikian, ada kriteria-kriteria tertentu yang diatur dalam hukum Islam yang memungkinkan suatu tindak kejahatan tersebut dapat dijatuhi hukuman mati. ${ }^{21}$

Munculnya perdebatan tentang hukuman mati sebagaimana telah dijelaskan pada akhirnya melahirkan setidaknya dua kelompok besar, yaitu kelompok yang ingin menghapus hukuman mati dan kelompok yang mendukung penerapan hukuman mati. Bagi kalangan yang menolak, hukuman mati merupakan bentuk pembunuhan yang dilegalkan oleh negara dan hal ini melanggar hak asasi manusia, karena hak hidup adalah hak dasar yang tidak bisa dikurangi dengan alasan apa pun (non-derogable rights) oleh individu. Sedangkan kelompok yang mendukung, hukuman mati adalah satu bentuk hukuman yang masih dibutuhkan untuk membuat efek cegah dan mengurangi kejahatan-kejahatan yang tergolong besar atau luar biasa di tengah masyarakat.

Menurut Suhaidi, Guru Besar pada Fakultas Hukum Universitas Sumatera Utara bahwa hukuman mati perlu diterapkan terhadap pelaku kejahatan berat seperti pembunuhan secara sadis dan bandar narkoba. Tujuannya adalah untuk membuat efek jera, sehingga masyarakat merasa takut melakukan perbuatan salah dan melanggar hukum. Jadi penerapan hukuman mati itu janganlah dianggap sebagai suatu balas dendam atau pelanggaran HAM terhadap pelaku kejahatan. Penilaian seperti ini tidak dapat diterima, apalagi dikait-kaitkan pula bahwa tindakan itu tidak manusiawi. ${ }^{22}$

Hudûd adalah hukuman-hukuman yang telah ditentukan bentuknya oleh Syar'i dengan nash-nash yang jelas. Hukuman hâadd menurut Hanafiyah ada lima macam yaitu, hâadd zina, $\underline{h} \hat{a} d d$ qadzf, $\underline{h} \hat{a} d d$ pencurian, $\underline{h} \hat{a} d d$ minum khamr, dan $\underline{h} \hat{a} d d$ mabuk. Sedangkan

\footnotetext{
${ }^{18}$ Hukuman maksimal yaitu hukuman mati bisa diberlakukan oleh suatu negara jika dipandang sebagai upaya efektif menjaga ketertiban dan kemaslahatan masyarakat. Khaeron Sirin, "Eksekusi Mati Trio Bom Bali," dalam Tempo, 25 Nopember 2008.

${ }^{19}$ Ibid.

${ }^{20}$ Barda Nawawi Arief, Bunga Rampai Kebijakan Hukum Pidana (Bandung: Citra Aditya, 1996), h. 99.

${ }^{21}$ Zafrullah Khan Muhammad, Islam and Human Rights (Islamabad: Islam International Publications Ltd., 1988), h. 74.

${ }^{22}$ http://www.antara.co.id/view/?i=1197825088\&c=NAS\&s=. 22 September 2011.
} 
menurut jumhur ulama selain Hanafiyah ada tujuh macam yaitu hâadd zina, $\underline{h} \hat{a} d d$ qadzf, hâadd pencurian, hâdd hirâbah, hâadd mabuk-mabukan, hâadd qishâsh, dan hâadd riddah. ${ }^{23}$

Ta'zîr adalah hukuman yang tidak ditentukan oleh syara', tetapi bentuk dan ketentuannya diserahkan kepada wali al-amr (negara) dengan memperhatikan perbedaan waktu dan tempat. Hukuman mati merupakan salah satu alternatif hukuman yang diberikan kepada para pelaku tindak pidana hudûd. Namun demikian hukuman mati hanya diberikan kepada empat pelaku $\underline{h} u d \hat{u} d$, yaitu:

\section{Zina Muhshan}

Zina adalah hubungan kelamin antara laki-laki dengan perempuan tanpa adanya ikatan perkawinan yang sah dan dilakukan dengan sadar serta tanpa adanya unsur syubhat. ${ }^{24}$ Delik perzinaan ditegaskan dalam al-Qur'an dan Sunnah. Hukuman bagi pelaku zina yang belum menikah (ghair muhshan) didasarkan pada ayat al-Qur'an, yakni didera atau dicambuk 100 kali. Sementara bagi pezina muhshan dikenakan sanksi rajam. Rajam dari segi bahasa berarti melempari batu. ${ }^{25}$ Rajam adalah melempari pezina muhshan sampai menemui ajalnya. ${ }^{26}$

Hukuman tersebut di atas dikenakan pada laki-laki dan perempuan. Karena Islam sangat menghargai kehormatan diri dan keturunan, maka sanksi yang sangat keras ini dapat diterima akal sehat. Allah SWT. berfirman "Pezina perempuan dan laki-laki hendaklah dicambuk seratus kali dan janganlah merasa belas kasihan kepada keduanya sehingga mencegah kamu dalam menjalankan hukum Allah, hal ini jika kamu beriman kepada Allah dan hari akhir. Dan hendaklah dalam menjatuhkan sanksi (mencambuk) mereka disaksikan oleh sekumpulan orang-orang yang beriman". ${ }^{27}$

Semua ulama sepakat tentang hukuman tersebut, namun yang membedakannya adalah apakah sebelum dirajam itu didera atau tidak. Menurut jumhur Ulama, orang yang harus dihukum rajam itu tidak didera. Sedang menurut al-Hasan al-Bashri, Ishaq, Ahmad dan Dawud, seorang yang pernah menikah dan melakukan zina dengan wanita lain maka sanksi hukumnya jilid kemudian dirajam. Oleh karena itu, hakim tidak boleh mengurangi, menambah, menunda pelaksanaanya, atau menggantinya dengan hukuman yang lain.

Ancaman keras bagi pelaku zina tersebut karena dalam pandangan Islam zina, merupakan perbuatan tercela yang menurunkan derajat dan harkat kemanusiaan secara

${ }^{23}$ Ibid.

${ }^{24}$ Muhammad Abû Zahrah, Al-Jarîmah wa al-'Uqûbah fî al-Fiqh al-Islâm, Juz III (Beirut: Dâr al-Fikr, t.t), h. 109.

${ }^{25}$ Teungku Muhammad Hasbi Ash-Shiddieqy, Tafsir al-Qur'an al-Majid al-Nur, Juz XI (New York: Crescent Star, 1965), h. 136.

${ }^{26}$ Abû Zahrah, Al-Jarîmah, h. 142.

${ }^{27}$ Q.S. al-Nûr/24: 2. 
umum. Apabila zina tidak diharamkan niscaya martabat manusia akan hilang karena tata aturan perkawinan dalam masyarakat akan rusak. Di samping itu pelaku zina berarti mengingkari nikmat Allah tentang kebolehan dan anjuran Allah untuk menikah. ${ }^{28}$ Hukuman delik perzinaan yang menjadi perdebatan di kalangan umat Islam adalah hukum rajam. Jumhur ulama menganggap tetap eksisnya hukum rajam, sekalipun bersumber pada khabar ahad. Sementara golongan Khawarij, Mu'tazilah dan sebagian fuqaha Syiah menyatakan, sanksi bagi pezina adalah hukum dera (cambuk). ${ }^{29}$

\section{Pembunuhan Sengaja}

Pembunuhan sengaja dalam syariat Islam diancam dengan beberapa macam hukuman, sebagian merupakan hukuman pokok dan pengganti, dan sebagian lagi merupakan hukuman tambahan. Hukuman pokok untuk pembunuhan sengaja adalah qishâsh dan kifarat, sedangkan penggantinya adalah diyat dan ta'zîr. Adapun hukuman tambahannya adalah penghapusan hak waris dan hak wasiat. Hukuman kifarat sebagai hukuman pokok untuk pembunuhan sengaja merupakan hukuman yang diperselisihkan oleh para fukaha. Syafi'iyah mengakuinya dengan mengiaskannya kepada pembunuhan karena kesalahan, sementara fukaha yang lain tidak mengakuinya.

Sebagaimana teks al-Qur'an menentukan bahwa "barangsiapa yang membunuh seorang mukmin dengan sengaja maka balasannya ialah Jahannam, kekal ia di dalamnya dan Allah murka kepadanya, dan mengutukinya serta menyediakan azab yang besar baginya". ${ }^{30}$ Pembunuhan bukanlah hal yang remeh dalam Islam. Al Qur'an bahkan menjelaskan penerapannya secara rinci. Allah SWT berfirman "Dan tidak layak bagi seorang mukmin membunuh seorang mukmin (yang lain), kecuali karena tersalah (tidak sengaja), dan barangsiapa membunuh seorang mukmin karena tersalah (hendaklah) ia memerdekakan seorang hamba sahaya yang beriman serta membayar diat (denda) yang diserahkan kepada keluarganya (si terbunuh itu), kecuali jika mereka (keluarga terbunuh) bersedekah. Jika ia (si terbunuh) dari kaum (kafir) yang ada perjanjian (damai) antara mereka dengan kamu, maka (hendaklah si pembunuh) membayar diat yang diserahkan kepada keluarganya (si terbunuh) serta memerdekakan hamba sahaya yang beriman. Barangsiapa yang tidak memperolehnya, maka hendaklah ia (si pembunuh) berpuasa dua bulan berturut-turut untuk penerimaan taubat dari Allah. Dan adalah Allah Maha Mengetahui lagi Maha Bijaksana."”1

Orang yang membunuh orang Islam (tanpa hak) harus diqisas (dibunuh juga). Jika ahli-ahli waris (yang terbunuh) memaafkannya, maka pelaku tidak dikisas (tidak

${ }^{28}$ Al-Jurjawî, al-Tasyri' wa Falsafâtuhu (Beirut: Dâr al-Fikr, t.t.), h. 316-318.

${ }^{29}$ Abd al-Rahman al-Jazirî, Kitâb al-Fiqh 'ala Mazhâhib Arba 'ah, Jilid IV (Beirut: Dâr al Fiqh, t.t.), h. 179.

${ }^{30}$ Q.S. al-Nisâ'/4: 93.

${ }^{31}$ Q.S. al-Nisâ'/4: 92. 
dihukum bunuh) tetapi harus membayar diyat (denda) yang besar, yaitu seharga 100 ekor unta tunai yang dibayarkan pada waktu itu juga. Berdasarkan hukuman tersebut, manfaat bagi keluarga terbunuh dan masyarakat secara umum menimbulkan rasa aman dan orang akan berpikir ribuan kali untuk membunuh orang lain tanpa $\underline{h} a q$.

\section{Perampokan (al-hirâbah)}

Hirâbah adalah keluarnya sekelompok bersenjata di daerah Islam dan melakukan kekacauan, penumpahan darah, perampasan harta, merusak kehormatan, merusak tanaman, peternakan, citra agama, akhlak, dan ketertiban umum, baik dari kalangan

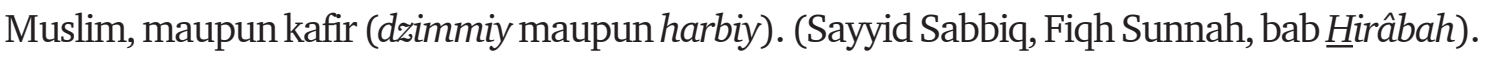
Termasuk dalam hirâbah, adalah kejahatan-kejahatan yang dilakukan oleh sindikat, mafia, dan triad. Misalnya, sindikat pencurian anak, mafia perampok bank dan rumah-rumah, sindikat para pembunuh pembayaran, dan tawuran massal.

Hirâbah berasal dari kata ' $\underline{h} a r b$ ' (peperangan). Para ulama sepakat bahwa tindakan hirâbah termasuk dosa besar yang layak dikenai sanksi hadd. Hukum hirâbah dibunuh, disalib, atau dipotong tangan dan kakinya secara bersilangan, atau dibuang dari negerinya. Ketentuan ini didasarkan pada firman Allah SWT. "Sesungguhnya pembalasan terhadap orang-orang yang memerangi Allah dan Rasul-Nya dan membuat kerusakan di muka bumi, tidak lain mereka itu dibunuh, atau disalib, atau dipotong tangan dan kaki mereka dengan bertimbal balik, atau dibuang dari negeri (tempat kediamannya); yang demikian itu adalah sebagai suatu penghinaan untuk mereka di dunia. Dan di akherat mereka memperoleh siksaan yang berat." 32

Rasulullah SAW. juga melaknat bahwa pelaku hirâbah tidak pantas mengaku sebagai seorang Islam. Sabda Rasulullah SAW "Barang siapa membawa senjata untuk mengacau kita, maka bukanlah mereka termasuk umatku!” (H. R. Bukhâri dan Muslim dari Ibnu ‘Umar).

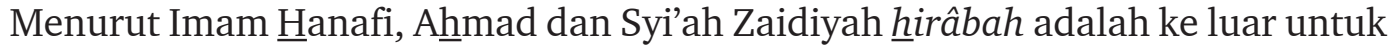
mengambil harta dengan jalan kekerasan yang realisasinya menakut-nakuti orang yang lewat di jalan atau mengambil harta, atau membunuh orang. Sedangkan menurut Syafi'iyah definisi hirâbah adalah ke luar untuk mengambil harta, atau membunuh, atau menakut-nakuti, dengan cara kekerasan, dengan berpegang kepada kekuatan, dan jauh dari pertolongan (bantuan). Menurut Imam Malik, hirâbah adalah mengambil harta dengan tipuan (taktik), baik menggunakan kekuatan atau tidak. Golongan Zhahiriyah memberikan definisi yang lebih umum, dengan menyebut pelaku hirâbah adalah perampok (muharib) adalah orang yang melakukan tindak kekerasan dan mengintimidasi orang yang lewat, serta melakukan perusakan di muka bumi. ${ }^{33}$

\footnotetext{
${ }^{32}$ Q.S. al-Mâ'idah/5: 33.

${ }^{33}$ Lihat "Konsep Hukum Pidana Islam Jarimah Hirobah," dalam http://ngobrol-islami.
} 
Hukuman bagi jarimah ini ditegaskan dalam al-Qur'an bahwa sesungguhnya pembalasan terhadap orang-orang yang memerangi Allah dan Rasul-Nya dan membuat kerusakan di muka bumi, hanyalah mereka dibunuh atau disalib, atau dipotong tangan dan kaki mereka dengan bertimbal balik, atau dibuang dari negeri (tempat kediamannya), yang demikian itu (sebagai) suatu penghinaan untuk mereka didunia, dan di akhirat mereka beroleh siksaan yang besar. ${ }^{34}$

\section{Pelaku Murtad (Riddah)}

Menurut bahasa Riddah adalah kembali dari sesuatu ke sesuatu yang lain. Sedangkan dalam kamus al-Munawwir riddah berasal dari kata: yang artinya menolak dan memalingkannya. Landasan hukuman mati untuk orang murtad dijelaskan dalam hadist Nabi SAW. yang bermakna “...dari Ibn 'Abbâs ra. Ia berkata: Rasulullah Saw bersabda: "Barang siapa menukar agamanya maka bunuhlah ia" (H. R. Bukhâri). Dalam hadits lain disebutkan, bahwa "Dari 'Aisyah ra. telah bersabda Rasulullah SAW, Tidak halal darah seorang muslim kecuali orang yang membunuh jiwa sehingga karenanya ia harus dibunuh, atau orang yang berzina dan ia muhshan, atau orang yang murtad setelah tadinya ia Islam" (H.R. Ahmad).

Dua hadis di atas menjelaskan bahwa murtad termasuk salah satu jenis tindak pidana yang diancam dengan hukuman mati. Untuk selain empat hal di atas ada jenis ta'zîr yang dikenai hukuman mati, misalnya untuk tindak pidana spionase (mata-mata) dan residivis yang sangat berbahaya. Oleh karena hukuman mati sebagai hukuman ta'zîr ini merupakan pengecualian maka hukuman tersebut harus dibatasi dan tidak boleh diperluas, atau diserahkan kepada hakim, seperti halnya hukuman ta'sîr yang lain. Dalam hal ini penguasa (ulil amri) harus menentukan jenis-jenis jarimah yang dapat dijatuhkan hukuman mati.

\section{Hukuman Mati Berdasarkan Hukum Pidana Indonesia}

Hukuman mati terhadap Imam Samudera dan kawan-kawan pelaku tindak pidana teroris pada penghujung tahun 2008, menjadi pertanda bahwa hukuman mati masih eksis di negara kita yang mayoritas berpenduduk muslim. Sementara itu, hampir 130 negara-negara di dunia telah melakukan moratorium bahkan penghapusan hukuman mati. Oleh karenanya, pembahasan berbagai dimensi hukuman mati dari perspektif keadilan sosial dan hukum menjadi sangat penting. Begitu juga dengan pandangan agama Islam, yang notabenenya dianut oleh sebagian besar warga negara Indonesia, dimensi hukuman mati

wordpress.com/2011/02/10/konsep-hukum-pidana-islam-jarimah-hirobah/. 10 Februari 2011.

${ }^{34}$ Q.S. al-Mâ'idah/5: 33. 
menjadi menarik untuk dikritisi lebih detail, karena di dalam hukum pidana Indonesia dengan tegas menyebutkan adanya pemidanaan mati.

Indonesia termasuk salah satu negara yang masih mempertahankan hukuman mati dalam sistem hukum positifnya, bahkan mencantumkannya dalam banyak undangundang. Hanya saja, sebagai negara yang menjunjung tinggi nilai-nilai HAM, negara Indonesia memberlakukan hukuman mati secara khusus, hati-hati, dan selektif. ${ }^{35}$ Penerapan hukuman mati ini secara filosofis diakui dan diakomodasi oleh konsep negara hukum Pancasila, meski nantinya bisa saja hukuman mati bersifat esepsional ataupun pidana bersyarat.

Dalam hukum pidana Indonesia, hukuman mati dengan tegas disebutkan dalam berbagai peraturan perundang-undangan yang ada. Bahkan dalam jenis-jenis hukuman yang diatur dalam Pasal 10 KUHP secara eksplisit menentukan eksistensi hukuman mati sebagai pidana pokok. Dalam KUHP, pidana mati dimungkinkan atas beberapa kejahatan, di antaranya adalah:

1. Pasal 104 tentang tindak pidana makar terhadap presiden dan wakil presiden;

2. Pasal 111 ayat (2) tentang tindak pidana membujuk negara asing untuk bermusuhan atau berperang, jika permusuhan itu dilakukan atau jadi perang;

3. Pasal 124 ayat (3) tentang tindakan membantu musuh waktu perang;

4. Pasal 140 ayat (3) tentang tindak pidana makar terhadap raja atau kepala negaranegara sahabat yang direncanakan dan berakibat maut;

5. Pasal 340 tentang tindak pidana pembunuhan berencana;

6. Pasal 365 ayat (4) tentang tindak pidana pencurian dengan kekerasan yang mengakibatkan luka berat atau mati;

7. Pasal 368 ayat (2) tentang tindak pidana pemerasan dengan kekerasan yang mengakibatkan luka berat atau mati;

8. Pasal 444 tentang tindak pidana pembajakan di laut, pesisir dan sungai yang mengakibatkan kematian.

Selain ketentuan tersebut di atas, ada beberapa undang-undang di luar KUHP yang menyebutkan tentang hukuman mati terhadap delik-delik tertentu. Misalnya, di dalam Undang-Undang No. 22 Tahun 1997 tentang Narkotika, Undang-Undang No. 31 Tahun 1999 Jo. Undang-Undang No. 20 Tahun 2001 tentang Pemberantasan Tindak Pidana Korupsi, Undang-Undang No. 15 Tahun 2003 tentang Terorisme, Undang-Undang No. 26 Tahun 2000 tentang Pengadilan Hak Asasi Manusia, Undang-Undang No. 5 Tahun 1997 tentang Psikotropika, Undang-Undang Darurat No. 12 Tahun 1951 tentang Senjata Api dan lain-lain.

\footnotetext{
${ }^{35}$ Todung Mulya Lubis dan Alexander Lay, Kontroversi Hukuman Mati: Perbedaan Pendapat Hakim Konstitusi (Jakarta: Gramedia, 2007), h. 335.
} 
Berdasarkan ketentuan tersebut di atas, hukuman mati hanya dijatuhkan apabila terdapat unsur-unsur tertentu saja. Misalnya Undang-Undang No. 31 Tahun 1999 Jo. Undang-Undang No. 20 Tahun 2001 tentang Pemberantasan Tindak Pidana Korupsi. Hukuman mati hanya diterapkan apabila korupsi dilakukan dalam keadaan tertentu. Maksud daripada keadaan tertentu adalah apabila seseorang yang secara melawan hukum melakukan perbuatan memperkaya diri sendiri atau orang lain atau suatu korporasi yang dapat merugikan keuangan negara atau perekonomian negara. ${ }^{36}$

Dalam ketentuan tersebut, pelaksanaan hukuman mati masih mengunakan metode tembak mati secara tertutup. Menurut Mantan Jaksa Agung Abdul Rahman Saleh, hukuman mati masih diperlukan sebagai upaya memberikan efek jera. ${ }^{37}$ Jaksa Agung hanya mengusulkan adanya perubahan metode hukuman mati, dari metode eksekusi tembak mati dengan metode lain seperti suntik mati atau digantung. Selama ini metode hukuman mati hanya dilakukan lewat tembak mati sesuai dengan Undang-Undang No. 2/PNPS/ 1964. Abdul Rahman Saleh pernah meminta kepada Ikatan Dokter Indonesia (IDI) untuk merekomendasikan metode hukuman mati lainnya. Namun IDI menolak merekomendasikan jenis hukuman mati lainnya. Keseriusan Jaksa Agung untuk mengubah metode hukuman mati juga ditunjukkan dengan membentuk Kelompok Kerja Hukuman Suntik Mati, yang melibatkan Mahkamah Agung (MA), IDI, Departemen Hukum dan HAM, Departemen Kesehatan, dan Polri. ${ }^{38}$

Kejaksaan Agung juga meminta fatwa MA untuk batas waktu Peninjauan Kembali dan Grasi dari terpidana mati supaya memiliki kepastian waktu untuk eksekusi. Namun, Pernyataan sikap yang lebih maju dikemukakan oleh mantan Ketua MA, Bagir Manan. Menurut Bagir Manan sebaiknya terpidana hukuman mati yang sudah divonis tetapi dalam waktu lima tahun tidak dieksekusi, maka hukumannya diubah menjadi pidana seumur hidup. ${ }^{39}$ Secara pasti, penetapan hukuman mati dalam beberapa undang-undang di Indonesia pada dasarnya telah melalui pembahasan di lembaga legislatif, yang notabene adalah para wakil rakyat, sebagai representasi dari seluruh rakyat Indonesia. Jika hukuman mati tetap dipertahankan, maka itulah pilihan bangsa Indonesia yang harus dihormati dan dipatuhi. Jika hukuman mati itu tidak disetujui lagi, maka rakyatlah yang harus menghapusnya.

${ }^{36} \mathrm{Hal}$ ini diatur dalam Pasal 2 ayat (2) Undang-Undang No. 31 Tahun 1999 Jo. UndangUndang No. 20 Tahun 2001 tentang Pemberantasan Tindak Pidana Korupsi. Penjelasan ketentuan ini menyebutkan bahwa yang dimaksud dengan ketentuan tertentu adalah pemberatan kepada pelaku tindak pidana korupsi apabila tindak pidana tersebut dilakukan pada waktu negara dalam keadaan bahaya sesuai dengan undang-undang yang berlaku, pada waktu terjadinya bencana alam nasional, sebagai pengulangan tindak pidana korupsi, atau pada saat negara dalam keadaan krisis ekonomi.

${ }^{37}$ Kompas, 9 April 2005.

${ }^{38}$ Tempo, 13 April 2005.

${ }^{39}$ Media Indonesia, 15 April 2005. 
Menurut van Bemmelen, mengutip pendapat J.J. Rousseau, pada dasarnya hukum secara menyeluruh bersandar pada suatu perjanjian masyarakat yang di dalamnya dinyatakan kehendak bersama. ${ }^{40}$ Jika terdapat tingkah laku yang menurut kehendak bersama tersebut harus dipidana, maka hal itu sejak awal harus diuraikan atau ditulis dalam undang-undang. Penguraian yang rinci dimaksudkan untuk menghindari pelanggaran kebebasan individu, sebab dalam perjanjian masyarakat, setiap orang hanya bersedia melepaskan sebagian kecil kebebasannya ke dalam wadah bersama itu. ${ }^{41}$

Begitu pula dengan hukuman mati. Sekiranya hukuman mati tersebut masih layak diberlakukan dan diterima oleh kehendak bersama, maka hukuman tersebut harus dituangkan dalam bentuk hukum tertulis (undang-undang). Hal itu berarti bahwa ketentuan hukuman mati dalam undang-undang di negara Indonesia pada dasarnya telah sesuai dengan teori perjanjian masyarakat atau konstitusi. Dalam konstitusi kita, ada jaminan penuh terhadap hak untuk hidup dan inilah pencerminan nilai-nilai hak asasi manusia (Pasal 28A dan Pasal 28I Ayat (1) UUD 1945).

Namun konstitusi kita tidak memberikan kebebasan tanpa batasan. Dalam Pasal 28J UUD 1945 menentukan bahwa:

a. Setiap orang wajib menghormati hak asasi manusia orang lain dalam tertib kehidupan bermasyarakat, berbangsa, dan bernegara.

b. Dalam menjalankan hak dan kebebasannya, setiap orang wajib tunduk kepada pembatasan yang ditetapkan dengan undang-undang dengan maksud semata-mata untuk menjamin pengakuan serta penghormatan atas hak dan kebebasan orang lain dan untuk memenuhi tuntutan yang adil sesuai dengan pertimbangan moral, nilai-nilai agama, keamanan, dan ketertiban umum dalam suatu masyarakat demokratis.

Ketentuan Pasal 28A dan Pasal 28I Ayat (1) UUD 1945 tersebut keberlakuannya dibatasi oleh ketentuan Pasal 28J UUD 1945. oleh karena itu, untuk melindungi kepentingan hukum nasional yang lebih besar, seharusnya dalam memahami ketentuan pidana atau hukuman mati di Indonesia tidak hanya membaca ketentuan Pasal 28A dan Pasal 28I UUD 1945, tetapi harus pula memperhatikan dan mengaitkannya dengan ketentuan Pasal 28J UUD 1945.

Dengan demikian, perdebatan hukuman mati dalam konteks demokrasi hendaknya lebih ditempatkan sebagai komoditas politik hukum ketimbang persoalan ideologis keagamaan. Munculnya dukungan kuat dari kalangan masyarakat terhadap eksistensi penerapan hukuman mati di Indonesia harus ditempatkan dalam konteks demokrasi, bukan dalam kerangka perjuangan ideologis.

Artinya, hukuman mati yang berlaku di Indonesia sekarang ini adalah hasil dari proses-

${ }^{40}$ J.M. van Bemmelen, Hukum Pidana I: Hukum Pidana Material Bagian Umum (Bandung: Binacipta, 1987), h. 50.

${ }^{41} I b i d$, h. 51. 
proses politik hukum dan demokrasi modern, tetapi pemahaman idiologi masyarakat tidak bisa dikesampingkan. Penerimaan pemberlakukan hukuman mati tidak terlepas dari pemahaman ideologi masyarakat yang dominan beragama islam. Apabila masyarakat kita sekuler maka sudah lama Indonesia mencabut atau menghapuskan hukuman mati sebagaimana yang dilakukan oleh sebagian besar negara-negara sekuler.

\section{Perdebatan Penerapan Hukuman Mati di Indonesia}

Perserikatan Bangsa-Bangsa (PBB) merupakan lembaga internasional yang secara tegas menolak praktik hukuman mati kepada semua terpidana, termasuk bagi para pelaku kejahatan genosida, kejahatan terhadap kemanusiaan, atau kejahatan perang. Semuanya merupakan kategori kejahatan di bawah hukum internasional yang paling serius. Saat ini, di tingkat internasional sudah terdapat empat instrumen Hak Asasi Manusia (HAM), satu bersifat internasional dan tiga bersifat regional yang khusus mengatur penghapusan hukuman mati. PBB telah mengeluarkan sebuah buku panduan berjudul Jaminan Perlindungan bagi mereka yang Menghadapi Hukuman Mati. ${ }^{42}$ Panduan ini memperjelas pembatasan-pembantasan praktik hukuman mati.

Lembaga HAM internasional secara tegas menentukan bahwa hukuman mati bertentangan dengan prinsip yang diatur di dalam Kovenan Internasional Hak-hak Sipil dan Politik (International Covenant on Civil and Political Rights). ${ }^{43}$ Para aktivis HAM dan beberapa organisasi kemanusiaan internasional menuntut penghapusan hukuman mati, karena dinilai melanggar hak hidup terpidana, menutup kesempatan untuk memperbaiki kesalahan dan bersosialisasi kembali kepada masyarakat.

Beberapa aktivis HAM menilai bahwa hukuman mati merupakan hukuman klasik yang sudah ketinggalan zaman (out of date) atau bentuk peninggalan masa lalu (a vestig of our savage past) yang harus dihindari. Sifat penghukuman yang keras dan represif tidak mampu memberikan solusi bagi permasalahan pidana modern dan sudah tidak relevan lagi dengan konteks modernitas yang menjunjung tinggi nilai-nilai kemanusiaan. ${ }^{44}$

Secara sosiologis, tidak ada pembuktian ilmiah bahwa hukuman mati akan mengurangi tindak pidana tertentu. Artinya hukuman mati telah gagal menjadi faktor determinan untuk menimbulkan efek jera, dibandingkan dengan jenis hukuman lainnya. Kajian PBB tentang

${ }^{42}$ Resolusi Dewan Ekonomi Sosial PBB No. 50 Tahun 1984, disahkan pada tanggal 25 Mei 1984. Buku Panduan ini disebut Safeguards Guaranteeing Protection of the Rights of Those Facing the Death Penalty.

${ }^{43}$ Hak untuk hidup (rights to life), yaitu pada Bagian III Pasal 6 ayat (1), menentukan bahwa setiap manusia berhak atas hak untuk hidup dan mendapatkan perlindungan hukum dan tiada yang dapat mencabut hak itu. Tim Imparsial, Terorisme: Definisi, Aksi, dan Regulasi (Jakarta: Imparsial, 2010), h. 8.

${ }^{44}$ William Schabas, "Islam and the Death Penalty," dalam William and Mary Bill of Rights Journal, Desember 2000, h. 223. 
hubungan hukuman dan angka pembunuhan antara 1988-2002 berujung pada kesimpulan bahwa hukuman mati tidak membawa pengaruh apa pun terhadap tindak pidana pembunuhan dari hukuman lainnya seperti hukuman seumur hidup. ${ }^{45}$

Dalam perkara permohonan uji materil terhadap Pasal 28I Undang-Undang Dasar 1945 di Mahkamah Konstitusi, E. Sahetapy berpandangan bahwa di Belanda sendiri, hukuman mati sudah dihapuskan sejak tahun $1870 .{ }^{46}$ Untuk itu, kenapa Wetboek van Strafrecht atau WvS (KUHP) masih harus dipertahankan. Apabila ingin mempertahankan hukuman mati, maka hal ini akan bertentangan dengan konsep Lembaga Pemasyarakatan karena Lembaga Pemasyarakatan berfungsi untuk memasyarakatkan kembali para narapidana.

Direktur Eksekutif Imparsial Rachland Nashidik mengatakan bahwa sebetulnya jenis dari apa yang disebut sebagai non derogable rights (hak yang tak bisa dikurangi dalam keadaan apa pun) itu berbeda-beda. Di dalam International Covenant on Civil and Political Rights (ICCPR) ada tujuh jenis non derogable rights yang diakui. Dalam European Convention on Human Rights cuma ada empat yang sudah dimaktubkan di dalam ICCPR. Negara Amerika sendiri, ada terdapat sebelas jenis hak yang diakui sebagai non derogable rights. Sebenarnya hak inti (The core of rights) dari non derogable rights tersebut ada empat hal. Pertama, Right to life, yaitu hak untuk bebas dari penyiksaan dan perlakuan yang merendahkan martabat. Kedua. Hak untuk tidak dianiaya. Ketiga. Right to free from slavery, yaitu hak bebas dari perbudakan atau diperhambakan. Keempat. Hak untuk tidak diadili oleh post facto law atau hukum yang berlaku surut.

Dalam permohonannya di Mahkamah Konstitusi, Henry Yosodiningrat menyebutkan bahwa ada sekitar 40 orang mati setiap hari akibat narkoba. Dalam sehari, nominal transaksi narkoba yang terjadi mencapai Rp. 800 miliar karena 4 juta orang yang kecanduan setidaknya per hari rata-rata melakukan transaksi sebesar Rp. 200.000,00 sehingga total setahun bisa mencapai Rp. 292 triliun. hampir seluruh lembaga pemasyarakatan, 70 persennya dihuni oleh pelaku kejahatan narkotika, baik itu pelaku maupun pengguna. Menurut Henry keberlakuan Pasal 28I UUD 1945 yang memuat ketentuan tentang non derogable rights, tidak boleh dipahami secara mandiri, melainkan dibatasi oleh ketentuan dalam Pasal 28J UUD 1945. ${ }^{47}$

Meningkatnya kejahatan narkoba, terorisme, atau kriminal lainnya tidak sematamata disebabkan oleh ketiadaan hukuman mati, namun oleh problem struktural lainnya

${ }^{45}$ http://www.kontras.org/hmati/index.php?hal=pers\&id=41. 2 Oktober 2010.

${ }^{46}$ Keterangan Ahli dalam Permohonan Uji Materil di Mahkamah Konstitusi yang dilakukan terhadap beberapa terpidana mati yang melakukan tindak pidana Narkotika berdasarkan UndangUndang No. 22 Tahun 1997 tentang Narkotika. Mereka beranggapan bahwa hukuman mati tersebut bertentangan dengan Pasal 28I Undang-Undang Dasar 1945.

${ }^{47}$ Lihat Jawaban dari Pengacara Pemohon Uji Materil Undang-Undang No. 22 Tahun 1997 Tentang Narkotika di Mahkamah Konstitusi yang dimohonkan oleh beberapa terpidana mati yang melakukan tindak pidana Narkotika. 
seperti kemiskinan atau aparatur negara yang korup. Bahkan untuk kejahatan terorisme hukuman mati umumnya justru menjadi faktor yang menguatkan berulangnya kembali tindakan pidana yang sama di masa yang akan datang. Hukuman mati justru menjadi amunisi ideologis untuk meningkatkan radikalisme dan militansi para pelaku.

Secara umum, beberapa instrumen internasional yang melarang adanya hukuman mati di dunia adalah:

a. Pasal 37 (a) Convention on the Rights of the Child, tahun 1989;

b. Pasal 3 Universal Declaration of Human Rights, tahun 1948;

c. Pasal 6 Kovenan Internasional Hak-hak Sipil dan Politik (ICCPR), tahun 1966;

d. Convention against Torture and Other Cruel, Inhuman or Degrading Treatment or Punishment, tahun 1984;

e. Second Optional Protocol of ICCPR aiming of The Abolition of Death Penalty, tahun 1990;

f. Protokol No. 6 European Convention for the Protection Human Rights and Fundamental Freedom, 1950 (berlaku mulai 1 Maret 1985);

g. The Rome Statute of International Criminal Court, 17 Juli 1998.

Perjuangan para pembela HAM untuk menghapus hukuman mati lebih didasarkan pada doktrin kemanusiaan, yaitu cinta kasih kepada sesama. Dalam hal ini, hukuman mati justru akan memunculkan lingkaran kekerasan, di mana setiap orang akan berada pada situasi ingin balas dendam, terluka dan rasa trauma. Dalam perspektif HAM Barat, jika kekerasan dibalas dengan kekerasan, maka hasilnya adalah kejahatan terus menerus. Berbeda jika, kekerasan dibalas saling memaafkan dan upaya cinta kasih. Jika konstitusi negara telah mengakui bahwa hak untuk hidup tidak dapat dikurangi atas alasan apa pun, maka penghapusan penerapan hukuman mati adalah sebuah kewajiban konstitusional.

Namun, anehnya PBB dan Amerika menutup mata ketika mantan Presiden Irak Saddam Hussein dijatuhi hukuman mati. ${ }^{48}$ Begitu juga terhadap beberapa kasus teroris,

${ }^{48}$ Pada 30 Desember 2006, di saat umat Muslim merayakan Idul Adha. Saddam Hussein divonis mati pada tanggal 5 November 2006 setelah pengadilan Irak (the Supreme Iraqi Criminal Tribunal) SICT) menyatakan ia bersalah atas pembunuhan terhadap 148 orang dari desa al-Dujail setelah upaya percobaan pembunuhan yang gagal terhadap dirinya di tahun 1982. Pengadilan Banding Irak kemudian memperkuat putusan pertama pada 26 Desember 2006 dan memerintahkan pelaksanaan eksekusi dalam kurun waktu 30 hari. Kemudian, Barzan Ibrahim al-Tikriti, Kepala Badan Intelejen Irak, dan Awad al Bandar, mantan Hakim Ketua pada Pengadilan Revolusioner Irak. Mereka divonis mati dengan dakwaan yang sama dengan Saddam. Eksekusi Saddam Hussein ini menimbulkan berbagai reaksi keras dari banyak perwakilan negara, khususnya dari komunitas Uni Eropa, beberapa Pelapor Khusus PBB, dan organisasi-organisasi HAM internasional. Eksekusi Saddam tidak hanya melanggar prinsip hak atas hidup yang tidak mentolerir praktek hukuman mati, namun juga eksekusi ini lahir lewat sebuah proses peradilan yang tidak jujur dan mandiri. "United Nations Human Rights Independent Expert Reiterates Concern About Saddam Hussein Trial and Death Sentence," diakses dalam http://www.unog.ch/unog/website/news_media.nsf/(http NewsByYear_en)/9B80E6578A747F43C12572570039CC43?OpenDocument, 28 Desember 2006. 
mereka melakukan pendekatan dan penekanan terhadap negara-negara yang terdapat pelaku teroris untuk menghukum mati pelaku tindak pidana teroris. Bahkan mantan Perdana Menteri Australia, John Howard meminta kepada Presiden Indonesia agar pelaku Bom Bali 1 dan Bom Bali 2 dihukum mati. ${ }^{49}$

Terlihat bahwa PBB dan negara-negara yang menolak hukuman mati berpendirian ganda terhadap kasus-kasus tertentu yang menyinggung kepentingan negara dan warga negaranya. Satu sisi menolak hukuman mati dengan alasan humanis tetapi di sisi lain justru memaksakan hukuman mati dilaksanakan. Bahkan hampir semua negara-negara yang menolak hukuman mati masih memberlakukan hukuman dengan cara tertentu terhadap delik tertentu.

Ada beberapa teori yang dapat dijadikan dasar untuk mendukung hukuman mati, antara lain teori Absolut, teori Relatif dan teori Gabungan. Menurut teori Absolut, syarat dan pembenaran dalam penjatuhan pidana tercakup dalam kejahatan itu sendiri, siapa yang mengakibatkan penderitaan, maka ia pun harus menderita. Hal tersebut tampak dalam pendapat Immanuel Kant yang menyebutkan bahwa dalam hukum, pidana tidak dapat dijatuhkan hanya sebagai sarana untuk memajukan kesejahteraan umum. Pemidanaan hanya dapat dijatuhkan pada seseorang karena ia bersalah melakukan kejahatan. ${ }^{50}$

Teori Relatif menyebutkan bahwa penjatuhan pemidanaan tergantung dari efek yang diharapkan dari penjatuhan pemidanaan itu sendiri, yakni agar seseorang tidak mengulangi perbuatannya. Hal tersebut tampak dalam pendapat Feuerbach dalam teorinya menghendaki penjeraan bukan melalui pidana, melainkan melalui ancaman pidana dalam perundang-undangan. Thomas Aquinas (teori gabungan) membedakan antara pidana sebagai pidana dan pidana sebagai obat. Ketika negara menjatuhkan pidana, maka perlu diperhatikan pula fungsi prevensi umum dan prevensi khusus. Dengan ajaran ini akan tercipta kepuasan nurani masyarakat dan ada pemberian rasa aman kepada masyarakat. Pembelajaran dan rasa takut juga akan muncul dalam masyarakat, termasuk perbaikan dari pelaku kejahatan. Negara dalam menjatuhkan pidana sebagai pembalasan, penjeraan,

${ }^{49}$ Australia telah menghapus hukuman mati sejak lahirnya Undang-Undang Penghapusan Hukuman Mati 1973. Namun wacana publik Australia tentang bagaimana menyikapi penerapan hukuman mati di luar negara itu kembali mencuat sehubungan dengan peringatan lima tahun insiden Bom Bali 12 Oktober 2002 dan kaitannya dengan rencana eksekusi Amrozi, Ali Ghufron dan Imam Samudera, para pelaku serangan yang menewaskan 202 orang, termasuk 88 warga Australia itu. Menurut mantan Hakim Ketua Pengadilan Tinggi Australia, Sir Gerard Brennan tentang sikap munafik kubu Koalisi Partai Liberal-Nasional yang berkuasa maupun kubu Partai Buruh Australia (ALP) yang menerima penerapan hukuman mati. Brennan seperti dikutip $A B C$ mengatakan, baik kubu koalisi maupun ALP tidak lagi bisa menyebutkan hukuman mati bagi warga negara Australia merupakan tindakan barbar sedangkan eksekusi mati bagi orangorang Indonesia "dapat diterima". "Howard Dinilai Munafik Soal Hukuman Mati," dalam www.gatra.com. Brisbane, 2 November 2007.

${ }^{50}$ Jan Remmelink, Hukum Pidana (Jakarta: Gramedia Pustaka Utama, 2003), h. 600. 
dan perbaikan disubordinasikan terhadap kemanfaatan dari penjatuhan pidana tersebut. Pidana sebagai pembalasan dipandang sebagai sarana untuk menegakkan tertib hukum. ${ }^{51}$

Selama ini, banyak tuduhan terhadap konsep hukuman mati, utamanya yang diatur dalam hukum Islam, yang seringkali digambarkan sebagai sesuatu yang kejam, tidak manusiawi dan sadis. ${ }^{52}$ Kesan mengerikan di balik hukuman mati tersebut adalah kesan populer yang menyelimuti penerapan hukum pidana Islam di masyarakat modern. Kesan ataupun kritik tersebut, yang awalnya dilancarkan oleh Barat, bukan semata karena mereka tidak suka terhadap konsep hukuman fisik, tetapi lebih disebabkan perasaan moral mereka yang belum terbangun seutuhnya.

Adanya kritik tersebut juga dikarenakan tidak disadarinya alasan keagamaan (spiritual) dari adanya hukuman tersebut, yaitu hukuman bukanlah dijatuhkan secara kejam oleh seseorang kepada orang lain, tetapi semata-mata demi melaksanakan ketentuanketentuan yang tercantum dalam doktrin hukum agama (Islam) yang terlingkup dalam maqâshid al-syarî‘ah.

Dalam hal ini, hukum Islam sangat memperhatikan nilai-nilai dasar kemanusiaan di dunia yang terlingkup pada lima hal, yaitu agama (al-dîn), jiwa (al-nafs), harta (al-mâl), akal (al-‘aql), dan keturunan (al-nasb). Perlindungan hak-hak ini sama sekali bukan karunia penguasa atau karunia masyarakat, tetapi merupakan karunia Allah SWT. Demi memelihara kelima hak dasar kemanusiaan tersebut, hukum Islam secara konsekuen mencantumkan hukuman mati sebagai salah satu hukuman pokok, sekaligus hukuman maksimal. Dari sinilah, para pendukung hukuman mati, yang sebagian besar terdiri dari masyarakat Islam, mendukung penerapan hukuman mati sebagai hukuman maksimal di Indonesia.

Dukungan terhadap hukuman mati dikuatkan lagi oleh Majelis Ulama Indonesia (MUI) dengan mengeluarkan fatwa tentang hukuman mati pada acara Musyawarah Nasionalnya yang ke-7 pada 28 Juli 2005 di Jakarta. MUI mendukung hukuman mati untuk kejahatan tertentu. Fatwa hukuman mati merupakan satu dari sebelas fatwa MUI lainnya seperti mengharamkan perkawinan beda agama, mengharamkan pluralisme, menyatakan Ahmadiyah sebagai ajaran sesat, dan sebagainya.

Presiden Susilo Bambang Yudhoyono dalam debat Capres dan Cawapres yang diselenggarakan oleh Komisi Pemilihan Umum (KPU) di Hotel Borobudur menyatakan bahwa hukuman mati kepada pengedar narkoba, koruptor, dan pelanggar berat HAM merupakan keadilan yang harus ditegakkan dan memberikan efek jera bagi para pelakunya. ${ }^{53}$ Salah satu kebijakan yang penting dalam mempertahankan hukuman mati dalam sistem hukum pidana Indonesia adalah terlihat dari pernyataan Wakil Presiden

${ }^{51}$ Ibid., h. 601-603.

${ }^{52}$ Muhammad Iqbal Siddiqi, The Penal Law of Islam (Lahore: Kazi Publications 1985), h. 30.

${ }^{53}$ Tim Imparsial, "Studi Kebijakan Imparsial, Jalan Panjang Menghapus Praktek Hukuman Mati di Indonesia," Laporan Penelitian, Juni 2004, h. 23. 
Jusuf Kalla yang dengan tegas menolak usulan dari Uni Eropa agar Indonesia menghapuskan pemidanaan mati pada rancangan KUHP yang baru. ${ }^{54}$ Bahkan pada tingkat kebijakan terhadap delik-delik tertentu, Presiden Republik Indonesia menegaskan bahwa tidak akan memberikan grasi terhadap para terpidana mati tindak pidana narkoba. ${ }^{55}$

Ketua Mahkamah Konstitusi sangat mendukung penerapan hukuman mati terhadap pelaku tindak pidana korupsi. Menurut Mahfud MD, negara Indonesia harus belajar dari negara China. Negara China pada tahun 2009 telah menghukum mati koruptor sebanyak 5.000-an orang. Salah satunya adalah Xiao Hongbo, Deputi Manajer Bank Konstruksi China. Xiao dieksekusi karena selama tiga tahun yaitu dari tahun 1998 sampai dengan 2001 mengkorupsi uang negara sebanyak Rp 3,9 Miliar dari salah satu bank milik negara di Dacheng, Provinsi Sichuan. ${ }^{56}$

Amnesti Internasional protes terhadap hukuman mati tersebut tetapi Perdana Menteri Zhu Rongji tidak peduli. Baginya, hukuman mati adalah jalan untuk menyelamatkan Cina dari kehancuran. Sejak dilantik menjadi Perdana Menteri Zhu Rongji pada tahun 1998, Zhu menyatakan dengan tegas memerangi tindak pidana korupsi. Perdana Menteri Zhu Rongji menyebutkan bahwa "berikan kepada saya seratus peti mati, sembilan puluh sembilan untuk koruptor dan satu untuk saya jika saya melakukan hal yang sama." Keberhasilan pemberantasan korupsi di China berdampak pada pertumbuhan ekonomi negara tersebut. Pada tahun 2009, barang-barang dan jasa yang dihasilkan atau produk domestik bruto China terus meningkat mencapai US\$ 4,2 triliun. Perekonomian Cina telah menjadi salah satu kekuatan ekonomi dunia. ${ }^{57}$

\section{Penutup}

Berdasarkan uraian tersebut di atas dapat disimpulkan bahwa hukuman mati bukanlah pelanggaran hukum, karena penerapan hukuman mati ditegakkan dalam rangka melindungi lembaga-lembaga kehidupan. Hidup ini merupakan hak asasi bagi setiap orang, maka negara atas nama hukum melindungi warganya dari peristiwa-peristiwa hukum yang merugikan masyarakatnya. Walaupun tidak sama pengakuan terhadap hukuman mati dengan hukum pidana Islam, hukum pidana Indonesia masih memberlakukan hukuman mati secara hati-hati dan dengan batasan-batasan yang telah ditentukan oleh undangundang. Dengan batasan-batasan inilah diharapakan dapat mengimbangi pandangan pro dan kontra antara yang mendukung dan menolak hukuman mati di Indonesia.

\footnotetext{
${ }^{54}$ Usulan Uni Eropa tersebut disampaikan oleh Dubes Finlandia, Markku Nilnloja, Dubes Jerman, Joachim Broudre Groger, serta delegasi Komisi Uni Eropa, Ulrich Eckle. Media Indonesia, 5 Juli 2006.

${ }^{55}$ The Jakarta Post, 1 Juli 2006 dan Tempo, 1 Juli 2006.

${ }^{56}$ Imron Rosyid, "Hukuman Mati," http://www.beritasatu.com/articles/read/2010/10/ 1421/hukuman-mati-. 18 Oktober 2010.

${ }^{57}$ Ibid.
} 
Hukuman mati dalam hukum pidana Islam adalah untuk melindungi agama, jiwa, akal, keturunan dan harta. Pencerobohan terhadap kelima hak dasar kemanusiaan tersebut berupa zina muhshan, pembunuhan sengaja, hirâbah dan murtad. Dalam Hukum Islam juga dikenal hukuman mati untuk ta'zîr yaitu apabila hukuman mati tersebut dikehendaki oleh umum dan delik ini sangat berbahaya, misalnya spionase (mata-mata), residivis, narkoba, terorisme, pencucian uang dan korupsi, termasuk kategori hukuman ta'zîr yang disebut dengan al-qatl al-siyâsi', yaitu hukuman mati yang tidak diatur oleh al-Qur'an dan Sunnah, tapi diserahkan kepada negara, baik pelaksanaan ataupun tatacara eksekusinya.

Dalam kedua sistem hukum telah secara tegas mengakui dan melaksanakan hukuman mati. Artinya secara hukum, budaya dan agama hukuman mati dilegalkan. Tinggal lagi, pemerintah Indonesia memilih dan memilah mana delik-delik yang wajar untuk dijatuhi hukuman mati dan metode pelaksanaan hukuman mati mana yang sesuai dilakukan sehingga tujuan pemidanaan tersebut dapat tercapai.

\section{Pustaka Acuan}

Arief, Barda Nawawi. Bunga Rampai Kebijakan Hukum Pidana. Bandung: Citra Aditya, 1996.

Ash-Shiddieqy, Teungku Muhammad Hasbi. Tafsir al-Qur'an al-Majid al-Nur, Juz XI. New York: Crescent Star, 1965.

Audah, 'Abd al-Qadir. al-Tasyri' al-Islâmi Jina'iy: Muqâranah bi al-Qanûn al-Wadh'i, Juz I. Beirut: al-Risâlah Muassasah, 1992.

Abû Zahrah, Muhammad. Al-Jarîmah wa al-'Uqûbah fî al-Fiqh al-Islâm, Juz III. Beirut: Dâr al-Fikr, t.t.

Abû Zahrah, Muhammad. Ushûl al-Fiqh. Kairo: Maktabah Muhaimar, 1957.

Badan Pekerja Kontras. "Praktik Hukuman Mati di Indonesia." diakses dalam http:// www.kontras.org, diunduh. 30 Desember 2008.

Bemmelen, J.M. van. Hukum Pidana I: Hukum Pidana Material Bagian Umum. Bandung: Binacipta, 1987.

Hamzah, Andi, et al. Pidana Mati di Indonesia di Masa Lalu, Masa Kini dan Masa yang Akan Datang, cet. 2. Jakarta: Ghalia Indonesia, 1985.

http://www.antara.co.id/view/?i=1197825088\&c=NAS\&s=. 22 September 2011.

http://www.legalitas.org/?q=content/dilema-hukuman-mati. 30 Desember 2008.

http://www.kontras.org/hmati/index.php?hal=pers\&id=41. 2 Oktober 2010.

"Death Penalty Development in 2005," dalam Amnesty International, diakses http:// web.amnesty.org/pages/deathpenalty-developments2005-eng.

Faiz, Pan Mohamad. "Perdebatan Konstitusionalitas Hukuman Mati," dalam the Jakarta Post, 4 Mei 2007. 
MIQOT Vol. XXXVI No. 2 Juli-Desember 2012

"Howard Dinilai Munafik Soal Hukuman Mati," dalam www.gatra.com. Brisbane, 2 November 2007.

Al-Jazirî, 'Abd al-Rahman. Kitâb al-Fiqh 'ala Mazhâhib Arba 'ah, Jilid IV. Beirut: Dâr alFiqh, t.t.

Al-Jurjawî. al-Tasyri' wa Falsafâtuhu. Beirut: Dâr al-Fikr, t.t.

Al-Khalâf, 'Abd al-Wahab. Science Ushûl al-Fiqh. Kuwait: Dâr al-Qalam, 1992.

Kompas, 29 Pebruari 2003.

Kompas, 9 April 2005.

Lubis, Todung Mulya, dan Alexander Lay, Kontroversi Hukuman Mati: Perbedaan Pendapat Hakim Konstitusi. Jakarta: Gramedia, 2007.

"Konsep Hukum Pidana Islam Jarimah Hirobah," dalam http://ngobrol-islami.wordpress. com/2011/02/10/konsep-hukum-pidana-islam-jarimah-hirobah.10 Februari 2011.

Media Indonesia, 15 April 2005.

Media Indonesia, 5 Juli 2006.

Muhammad, Zafrullah Khan. Islam and Human Rights. Islamabad: Islam International Publications Ltd., 1988.

Schabas, William. Discussion on Death Penalty Contemporary Challenges, Delegation of European Commission and Departemen of Philosofy Faculty of Humanities University of Indonesia, Hotel Mandarin Jakarta, 14 Desember 2004.

Prayitno, Sudi. "Dilema Hukuman Mati." dalam http://www.legalitas.org/?q=content/ dilema-hukuman-mati. 30 Desember 2008.

Rosyid, Imron. "Hukuman Mati," http://www.beritasatu.com/articles/read/2010/10/ 1421/hukuman-mati-. 18 Oktober 2010.

Remmelink, Jan. Hukum Pidana. Jakarta: Gramedia Pustaka Utama, 2003.

Siddiqi, Muhammad Iqbal. The Penal Law of Islam. Lahore: Kazi Publications 1985.

Sahetapi, J. E. Suatu Studi Khusus Mengenai Ancaman Pidana Mati terhadap Pembunuhan Berencana. Jakarta: Rajawali, 1982.

Schabas, William. "Islam and the Death Penalty," dalam William and Mary Bill of Rights Journal, Desember 2000.

Sirin, Khaeron. "Eksekusi Mati Trio Bom Bali,” dalam Tempo, 25 Nopember 2008.

The Jakarta Post, 1 Juli 2006 dan Tempo, 1 Juli 2006.

Tempo, 13 April 2005.

Tim Imparsial. "Studi Kebijakan Imparsial, Jalan Panjang Menghapus Praktek Hukuman Mati di Indonesia," Laporan Penelitian, Juni 2004.

Tim Imparsial, Terorisme: Definisi, Aksi, dan Regulasi. Jakarta: Imparsial, 2010.

"United Nations Human Rights Independent Expert Reiterates Concern About Saddam Hussein Trial and Death Sentence," diakses dalam http://www.unog.ch/unog/website/ 
news_media.nsf/(httpNewsByYear_en)/9B80E6578A747F43C1257257 0039CC43?OpenDocument, 28 Desember 2006.

Yahya, Imam. "Hukuman Mati Perspektif Syari'ah." dalam http://imamyahya.blogspot.com/ 2009/04/hukuman-mati-perspektif-syariah.html. Selasa, 14 April 2009. 